\title{
PENGEMBANGAN MEDIA POHON BERSUARA BERBASIS MODEL CHILDREN LEARNING IN SCIENCE UNTUK MENINGKATKAN PRESTASI BELAJAR FISIKA SISWA SDN DI TRENGGALEK
}

\author{
Wahyuni Fajar Arum ${ }^{1, \text { a) }}$, Aditya Dewantari ${ }^{2, \text { b) }}$ \\ ${ }^{1}$ Prodi D3 Aeronautika, Sekolah Tinggi Teknologi Kedirgantaraan Yogyakarta, Jl Parangtritis KM 4.5 \\ Yogyakarta \\ ${ }^{2}$ Prodi D4 Manajemen Transportasi Udara, Sekolah Tinggi Teknologi Kedirgantaraan Yogyakarta, Jl \\ Parangtritis KM 4.5 Yogyakarta
}

Email: a) wahyunifajararum@gmail.com, b) aditya.dewantari@gmail.com

\begin{abstract}
Abstrak
Pada proses pembelajaran terdapat beberapa permasalahan terutama berkaitan dengan motivasi dan hasil belajar siswa ketika di kelas. Ketidaktertarikan siswa terutama pada mata pelajaran Fisika yang penuh dengan hafalan dan angka menyebabkan siswa menjadi cepat bosan karena metode daan media pembelajaran yang digunakan kurang menarik. Tujuan dari penelitian ini adalah 1) mengetahui proses pembelajaran yang sebelumnya digunakan di Sekolah Dasar Negeri Trenggalek, 2) menjelaskan prosedur pengembangan media pembelajaran pohon bersuara menggunakan model pembelajaran Children Learning in Science serta 3) mengetahui peningkatan prestasi belajar siswa. Metode penelitian dan pengembangan yang digunakan adalah Research and Development (RnD). Pengembangan model pembelajaran dilakukan dengan menggunakan model pembelajaran Children Learning in Science. Validasi penggunaan media pembelajaran dilakukan di SDN 1 Ngembel Kelas V kemudian diimplementasikan ke SDN 2 Ngembel pada kelas V. Hasil penelitian dan pengembangan yaitu 1) proses pembelajaran di SDN Ngembel 1dan 2 masih menggunakan metode ceramah, 2) media pembelajaran pohon bersuara yang dikembangkan dengan model pembelajaran berbasis Children Learning in Science dilengkapi dengan metode eksperimen sehingga memudahkan siswa menyerap mata pelajaran Fisika, 3) prestasi belajar Fisika kelas V SDN 1 Ngembel dan SDN 2 Ngembel Trenggalek mengalami peningkatan rata-rata nilai 40\%. Peningkatan nilai prestasi belajar dilihat dari nilai pretest dan post test.
\end{abstract}

Kata-kata kunci: media pembelajaran, pohon bersuara, CLIS, Fisika.

\begin{abstract}
In the learning process, there are some problems mainly related to motivation and student learning outcomes. Students feel uninterested in Physics because its full of memorization and numbers it makes students get bored quickly due to uninteresting learning method. The purpose of this research is 1) to know the learning process previously used in Trenggalek State Elementary School, 2) to explain the procedure of developing voice-learning tree media using Children Learning in Science model, 3) to know the improvement if student's learning achievement because of the use of media. The method used in this research is Research and Development $(\mathrm{RnD})$. The development of a learning model is done by using Children Learning in Science. Validation about this use of media had been done in SDN 1 Ngembel Class V then implemented to SDN $2 \mathrm{Ngembel}$ in class V. The result of research are 1) learning process at SDN Ngembel 1 and 2 still using lecturing method, 2) voice learning tree media is developed with Children Learning in Science equipped with experimental method, thus students are enabled to learn Physics
\end{abstract}


material, 3) Physics learning achievement at class V SDN 1 Ngembel and SDN 2 Ngembel Trenggalek experienced an average increase of $40 \%$. The increase in the value of learning achievement is from the results of pretest and posttest.

Keywords: learning media, voice-learning tree, CLIS, Physics.

\section{PENDAHULUAN}

Pendidikan merupakan salah satu faktor terpenting dalam pembangunan Indonesia. Pendidikan mempunyai peranan penting dalam memperbaiki kualitas sumber daya manusia yang dimiliki. Upaya peningkatan kualitas pendidikan yang sesuai dengan perkembangan jaman dan teknologi dapat meningkatkan martabat dan peran Indonesia di mata dunia. Peningkatan dan pembaharuan di dalam bidang pendidikan harus terus dilakukan agar tujuan utama dari pendidikan Indonesia bisa tercapai. Peningkatan tersebut dapat dilakukan dalam bidang pembaharuan model pembelajaran maupun pembaharuan dalam bidang media pembelajaran yang digunakan.

Setiap manusia secara psikologis mengalami tahap pertumbuhan dan perkembangan yang berlangsung secara teratur dan terus menerus. Perkembangan anak meliputi beberapa aspek pertumbuhan dan perkembangan baik secara fisik maupun mental. Di negara Indonesia usia rata-rata anak masuk sekolah dasar [1] adalah ketika berusia 6 tahun dan akan lulus sekolah dasar pada usia 12 tahun. Pada dasarnya tugas anak pada usia sekolah dasar menurut Havighurst [2] meliputi: 1) belajar keterampilan fisika, 2) membentuk sikap yang sehat terhadap dirinya sebagai makhluk yang sedang berkembang, 3) belajar bergaul dengan teman seusianya, 4) belajar dalam peran sosial sesuai sebagai pria atau wanita, 5) mengembangkan konsep ilmu bagi kehidupan sehari-hari, 6) mengembangkan pesan moralitas dan nilai-nilai kernormaan, 7) mencapai kebebasan pribadi sebagai manusia, 8) dan mengembangkan sikap-sikap terhadap kelompok-kelompok.

Menurut Jean Piaget [3] tahap perkembangan kognitif anak terdiri dari empat tahap yaitu sensor motoris, pra operasional, operasional konkret, dan operasional formal. Usia anak sekolah dasar ketika berada pada rentang 6-12 tahun termasuk pada operasional konkret di mana anak memiliki rasa ingin tahu yang kuat, senang bermain dalam suasana yang menggembirakan, mengatur diri dan orang di sekitarnya, mengeskplorasi situasi baru untu $=\mathrm{k}$ dicoba-coba, memiliki dorongan untuk bersaing dalam prestasi, tidak menyukai kegagalan, akan belajar secara efektif bila merasa suka dengan situasi yang ada, belajar dengan cara bekerja dan suka mengajarkan apa yang ia bisa kepada temannya.

Berdasarkan hal di atas, maka bisa kita ketahui bahwa siswa sekolah dasar berada pada tahap operasional konkret di mana memiliki objektivitas tertinggi, karena memiliki keinginan berprestasi, rasa keingintahuan yang besar, dan gemar bermain terhadap sesuatu yang baru dan menarik dengan teman sebaya di dalam kelompok-kelompoknya. Karakteristik siswa tersebut pada umumnya hampir dimiliki oleh siswa di sekolah dasar.

Pada pembelajaran Fisika seorang guru dituntut untuk merancang suatu proses pembelajaran menjadi kondusif, menarik, menyenangkan dan bermakna dengan media dan model pembelajaran yang variatif sehingga siswa akan memiliki ketertarikan melibatkan diri secara aktif dalam pembelajaran. Saat ini ada beberapa permasalahan dalam proses pembelajaran terutama berkaitan dengan motivasi dan hasil belajar siswa ketika di kelas. Ketidaktertarikan siswa terutama pada mata pelajaran Fisika yang penuh dengan hafalan dan angka menyebabkan siswa menjadi cepat bosan karena metode pembelajaran yang digunakan kurang menarik. Ketidaktertarikan siswa terhadap mata pelajaran Fisika ini bisa menyebabkan kurangnya partisipasi siswa dalam pembelajaran yang berpengaruh terhadap prestasi belajar siswa. Ada dua faktor yang mempengaruhi prestasi belajar siswa menjadi dua golongan yaitu, faktor-faktor internal (dalam) dan faktor-faktor eksternal (luar). Faktor internal sendiri dibedakan menjadi tiga faktor yaitu faktor jasmani, psikologi dan faktor kelelahan. Sedangkan untuk faktor eksternal dipengaruhi oleh tiga faktor, yaitu keluarga, sekolah, dan masyarakat [4].

Seorang guru harus peka terhadap permasalahan yang terjadi dalam proses belajar siswa di kelas. Permasalah belajar siswa yang tergambarkan diatas dapat diatasi oleh guru, salah satunya dengan memilih model pembelajaran yang tepat untuk mendukung proses belajar siswa di kelas. Berdasarkan 
hasil penelitian terdahulu yang dilakukan oleh Anwar dkk [5], aktivitas guru dan siswa dalam pembelajaran dengan menerapkan model Children Learning in Sience dapat meningkatkan hasil belajar dan mendapat respon yang sangat baik dari siswa. Children Learning in Sience adalah suatu model pembelajaran yang melibatkan siswa dalam kegiatan praktikum, eksperimen, menyajikan, mengintepretasi, memprediksi dan menyimpulkan dengan menggunakan Lembar Kerja Siswa [6].

Model Children Learning in Sience dapat diterapkan dengan bantuan media pembelajaran yang menarik untuk mempermudah siswa dalam memahami materi yang sedang dipelajari. Dalam penelitian ini, peneliti memilih media pembelajaran berupa pohon bersuara. Media pembelajaran pohon bersuara berbasis model Children Learning in Science merupakan media pembelajaran berbentuk pohon yang didesain penuh warna dan dengan bentuk yang menarik dengan berusaha mengembangkan ide atau gagasan sisa tentang suatu permasalahan Fisika dalam kehidupan sehari-hari berdasarkan hasil pengamatan mereka. Media pembelajaran pohon bersuara berbasis model Children Learning in Science akan mendorong siswa untuk memahami konsep-konsep sederhana Fisika dengan membaca dan menulis di pohon yang telah didesain untuk menarik minat dan motivasi belajar siswa. Media pembelajaran pohon bersuara berbasis model Children Learning in Science diharapkan akan memudahkan siswa dalam memahami mata pelajaran Fisika karena media pembelajaran akan dibuat dengan design yang semenarik mungkin dengan memanfaatkan kreatifitas siswa itu sendiri.

Tujuan dari penelitian ini adalah 1) mengetahui kondisi pembelajaran pada mata pelajaran Fisika siswa Sekolah Dasar Negeri di Trenggalek, 2) menghasilkan media pembelajaran pohon bersuara berbasis model Children Learning in Science untuk mata pelajaran Fisika di Sekolah Dasar Negeri di Trenggalek, serta 3) melihat pengaruh media pembelajaran pohon bersuara berbasis model Children Learning in Science terhadap peningkatan prestasi belajar siswa di Sekolah Dasar Negeri di Trenggalek.

\section{METODE PENELITIAN}

Model yang digunakan pada penelitian ini adalah metode Research and Development $(R n D)$. Pendekatan pada penelitian ini akan mengadopsi model Borg \& Gall yang terdiri atas 8 langkah yaitu meliputi 1) identifikasi kebutuhan siswa sekolah dasar di Trenggalek, 2) pengembangan produk awal, 3) evaluasi dan pengujian internal, 4) revisi atau penyempurnaan produk tahap pertama, 5) validasi produk, 6) revisi dan penyempurnaan produk tahap kedua, 7) uji coba, 8) finalisasi produk [7]. Pada penelitian ini akan mempelajari model pembelajaran Children Learning in Science dari peneliti sebelumnya kemudian mengkombinasikan model ini dengan media pembelajaran pohon bersuara yang sedang dikembangkan.

Teknik pengumpulan data pada penelitian ini adalah dengan cara melakukan studi literature, observasi, wawancara, tes pre test dan post test. Studi literatur dilakukan untuk mengumpulkan data mengenai media-media pembelajaran khususnya untuk mata pelajaran Fisika yang sudah ada serta penelitian berkaitan dengan model pembelajaran Children Learning in Science. Observasi dilakukan untuk mengamati hasil uji coba desain dan produk yang telah dibuat. Wawancara dilakukan kepada guru dan siswa untuk melihat proses pembelajaran yang dilakukan sebelum penelitian pada mata pelajaran Fisika. Tes pre test dan post test digunakan untuk mengetahui peningkatan prestasi belajar siswa.

Teknik analisis data yang digunakan dalam uji coba luas media pembelajaran pohon bersuara berbasis model Children Learning in Science adalah Pre-Experimental Design dengan tipe onegroup Pretest-Posttest Design. Pretest dan Posttest dilakukan untuk membandingkan secara lebih akurat keadaan sebelum dan sesudah perlakuan.

\section{HASIL DAN PEMBAHASAN}

Penelitian untuk pengembangan media pohon bersuara berbasis model Children Learning In Science dilakukan di SDN 1 Ngembel dan SDN 2 Ngembel Kecamatan Watulimo Kabupaten Trenggalek. Pelaksaan penelitian dilakukan selama 4 hari berturut-turut dengan mengambil materi 
Fisika berkaitan dengan gaya dan gerak, pesawat sederhana, serta cahaya. Instrumen penelitian yang digunakan adalah RPP, LKS, dan tes tertulis. Tes tertulis dilakukan untuk mengambil data pretest dan post test sehingga peneliti bisa melihat perbedaan prestasi belajar siswa setelah dan sesudah melakukan penelitian.

Pembelajaran yang dilakukan di SDN 1 Ngembel dan SDN 2 Ngembel berdasarkan hasil wawancara yang dilakukan peneliti kepada guru dan siswa selama ini hanya dilakukan dengan metode ceramah dan tes saja. Hal ini dikarenakan SDN 1 Ngembel dan SDN 2 Ngembel merupakan contoh sekolah yang terpencil karena sulit dijangkau bahkan oleh sinyal internet. Kekurangan ini menyebabkan mayoritas pembelajaran hanya dilakukan dengan menggunakan studi literatur dan dibantu dengan ceramah yang dilakukan oleh guru.

Model pembelajaran Children Learning in Science merupakan suatu model pembelajaran yang bertujuan untuk membentuk pengetahuan (konsep) ke dalam memori siswa agar konsep tersebut dapat bertahan lama, karena model pembelajaran Children Learning in Science memuat sederet tahap-tahap kegiatan siswa dalam mempelajari konsep yang diajarkan.

Tahap-tahap pada model Children Learning in Science digunakan dalam penyusunan perangkat pembelajaran dalam bentuk RPP selama 4 kali pertemuan. Tahap-tahap yang digunakan selama pembelajaran meliputi 1) tahap orientasi, 2) tahap pemunculan gagasan, 3) tahap penyusunan gagasan, 4) tahap penerapan gagasan, dan 5) tahap pemantapan gagasan.

Media pembelajaran pohon bersuara berbasis model Children Learning in Science pada penelitian ini merupakan media pembelajaran yang berasal dari imitasi pohon dengan ditambah dengan daun yang didesign menggunakan kertas karton berwarna yang dibentuk menjadi daun sesuai dengan design yang sudah ditentukan.

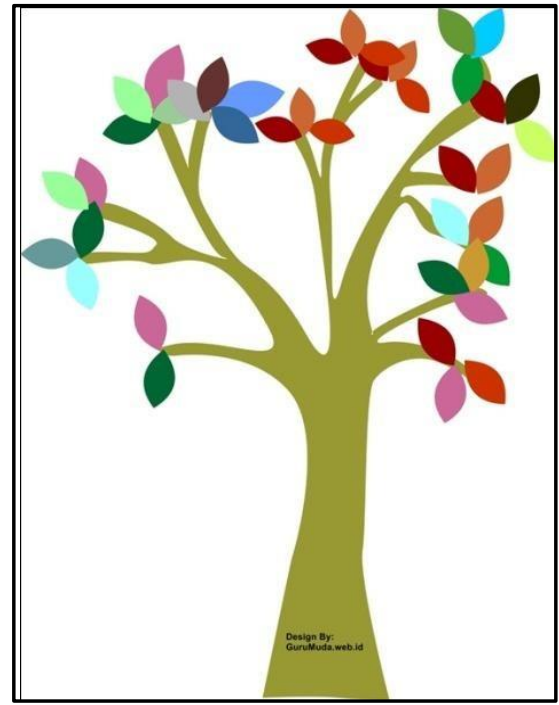

(a)

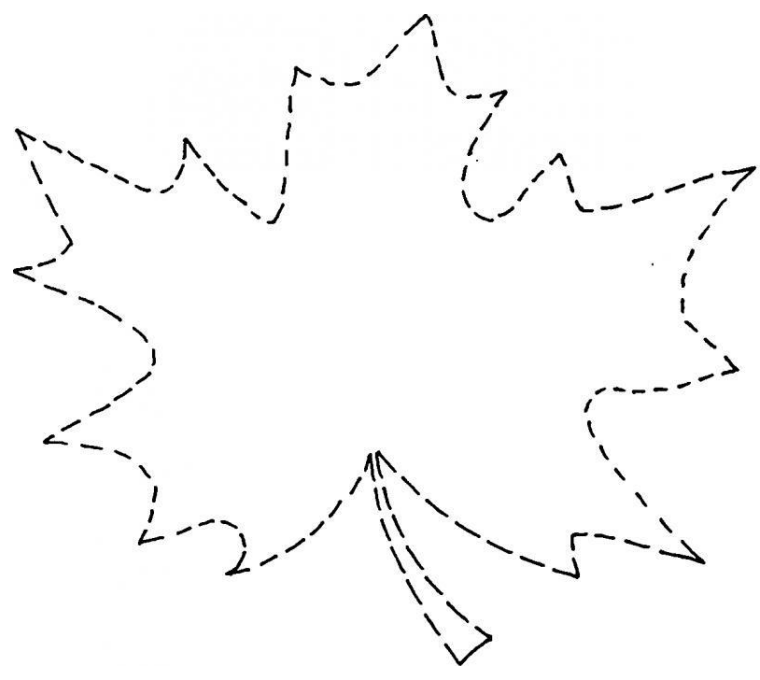

(b)

GAMBAR 1. (a) Design pohon imitasi yang digunakan dalam pembuatan media pembelajaran, (b) Design daun yang dipakai dalam pembuatan media pembelajaran

Daun yang sudah dipotong dan dibentuk digunakan siswa sebagai tempat siswa menuliskan permasalah serta penyelesaian masalah yang diberikan oleh guru sesuai dengan permasalahan Fisika yang berhubungan dengan materi yang diajarkan. 


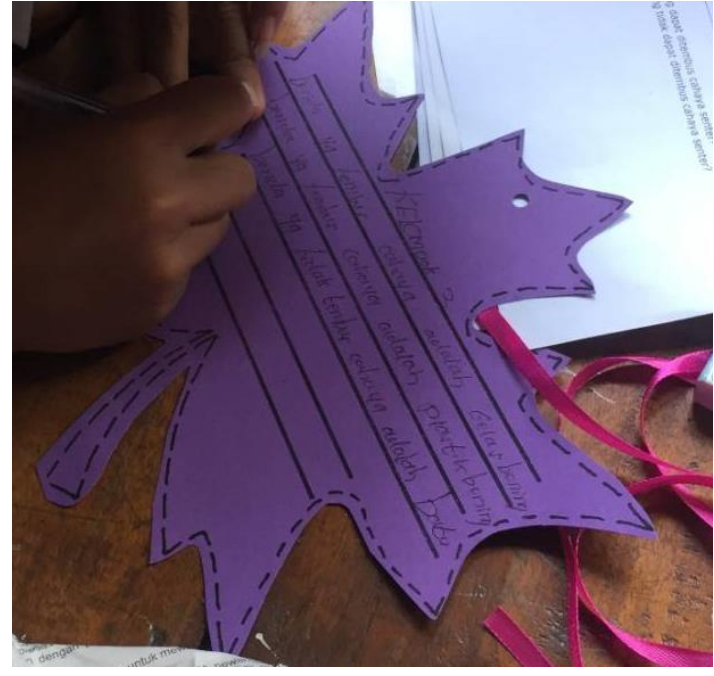

(a)

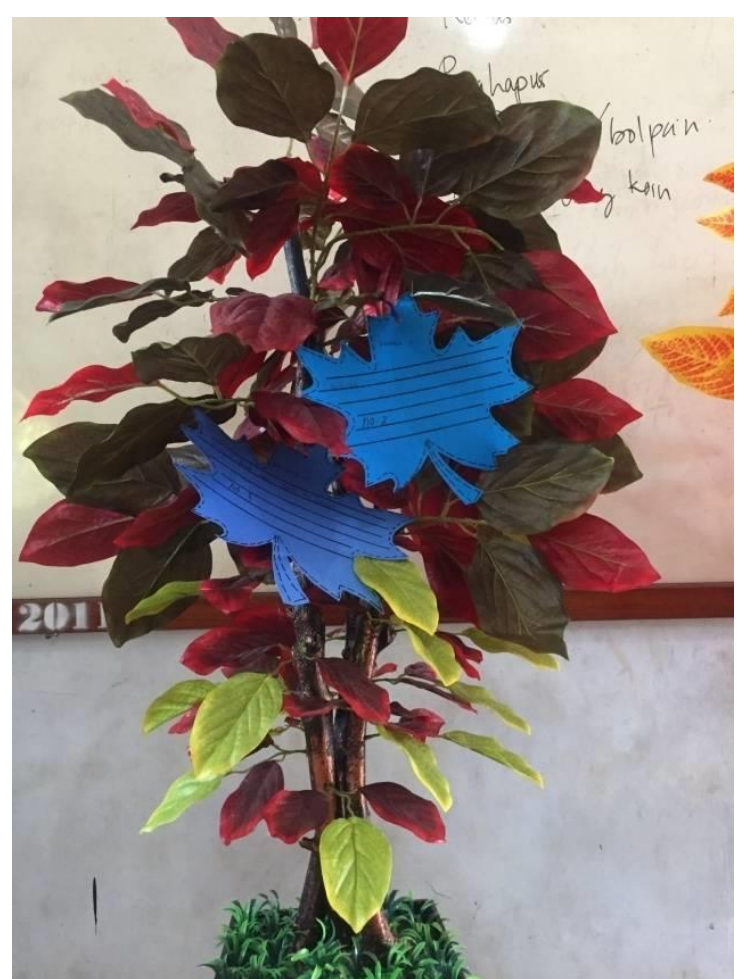

(b)

GAMBAR 2. (a) Daun imitasi yang sudah selesai dibuat siswa, (b) Hasil akhir dari media pembelajaran pohon bersuara

Selama proses pembelajaran siswa diminta membentuk kelompok-kelompok berisi 3-4 orang digunakan untuk menyelesaikan permasalahan-permasalahan sederhana yang diberikan oleh guru melalui LKS. Penyelesaian dalam setiap permasalahan di dalam LKS dituliskan dalam kertas yang telah dibuat oleh siswa dan akan diikatkan ke ranting pohon dengan seutas tali. SDN 1 Ngembel dan SDN 2 Ngembel merupakan contoh beberapa sekolah di kota kecil Trenggalek yang memiliki keterbatasan sarana dan prasana. Media pembelajaran pohon bersuara berbasis model Children Learning in Science ini dibuat untuk mengatasi permasalahan tersebut.

Prestasi belajar untuk penelitian dari pengembangan media pohon bersuara berbasis model Children Learning in Science dilihat dari nilai hasil tes tertulis pretest dan post test. Pretest dan post test berisi 20 soal pilihan ganda berkaitan dengan materi gaya dan gerak, pesawat sederhana, cahaya serta optik. Rata-rata hasil pretest dan post test SDN 1 Ngembel dan SDN 2 Ngembel bisa dilihat pada tabel 1 .

TABEL 1. Rata-rata Nilai pretest dan post test SDN 1 Ngembel dan SDN 2 Ngembel

\begin{tabular}{|c|c|c|c|}
\hline \multicolumn{2}{|c|}{ SDN 1 Ngembel } & \multicolumn{2}{|c|}{ SDN 2 Ngembel } \\
\hline Pre Test & Post Test & Pre-Test & Post-Test \\
\hline 25.71 & 68.92 & 25.35 & 66.43 \\
\hline
\end{tabular}

Berdasarkan data dari Tabel 1 maka terlihat bahwa sebelum penelitian dilakukan di SDN 1 Ngembel nilai pretest yang dihasilkan adalah 25.71, sedangkan setelah penelitian dilakukan nilai post test yang diperoleh adalah 68.92. Hal ini tidak berbeda jauh dari hasil penelitian yang diperoleh dari SDN 2 Ngembel. Berdasarkan data maka sebelum dilakukan penelitian nilai pretest adalah 25.35 sedangkan setelah penelitian nilai post test yang diperoleh adalah sebesar 66.43. Sehingga bisa disimpulkan dari data tabel 1 bahwa kenaikan nilai pretest dan post test dari kedua sekolah tersebut rata-rata mencapai $40 \%$. 
TABEL 2. Distribusi Frekuensi Prestasi Belajar Menggunakan Media Pohon Bersuara Berbasis Model Children Learning in Science

\begin{tabular}{|c|c|c|c|c|c|}
\hline \multicolumn{3}{|c|}{ SDN 1 Ngembel } & \multicolumn{3}{|c|}{ SDN 2 Ngembel } \\
\hline Nilai Interval & Frekuensi & Frekuensi Relatif & Nilai Interval & Frekuensi & Frekuensi Relatif \\
\hline $45-54$ & 1 & 7.14 & $45-54$ & & 7.14 \\
\hline $55-64$ & 2 & 14.29 & $55-64$ & & 28.57 \\
\hline $65-74$ & 6 & 42.86 & $65-74$ & & 28.57 \\
\hline $75-84$ & 5 & 35.71 & $75-84$ & & 35.71 \\
\hline
\end{tabular}

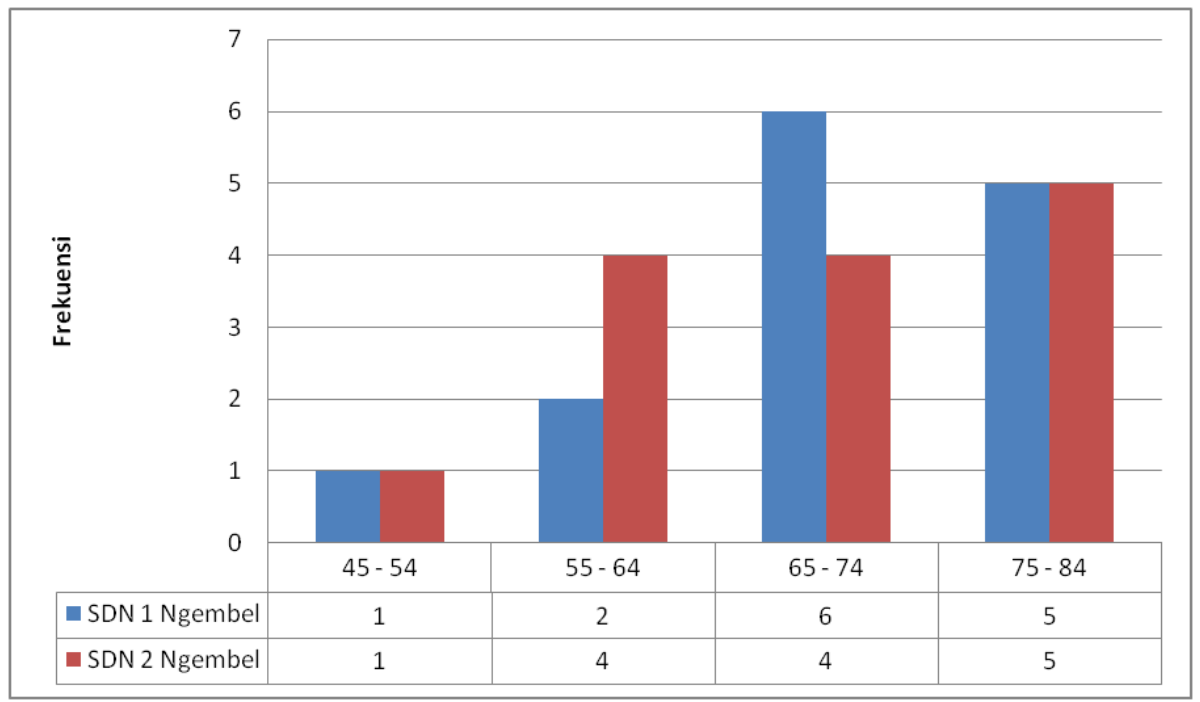

GAMBAR 3. Histogram Distribusi Frekuensi Prestasi Belajar Dengan Menggunakan Media Pohon Bersuara Berbasis Model Children Learning in Science

Berdasarkan tabel 1 dan gambar 3 distribusi data prestasi belajar yang diperoleh dari nilai post test di SDN 1 Ngembel frekuensi tertinggi terdapat pada interval 65 - 74 dengan frekuensi 6, sedangkan frekuensi terendah terdapat pada interval $45-54$ dengan frekuensi 1. Sedangkan untuk nilai prestasi belajar di SDN 2 Ngembel untuk frekuensi tertinggi terdapat pada interval 75 - 84 dengan frekuensi 5 , untuk frekuensi terendah terdapat pada interval 45 - 54 dengan frekuensi 1.

Uji hipotesis yang digunakan pada penelitian ini adalah dengan menggunakan uji T. Analisis uji T dengan SPSS digunakan untuk mencari pengaruh media pohon bersuara berbasis model Children Learning in Science terhadap prestasi belajar fisika siswa SDN di Trenggalek.

TABEL 3. Hasil Uji T Siswa SDN 1 Ngembel

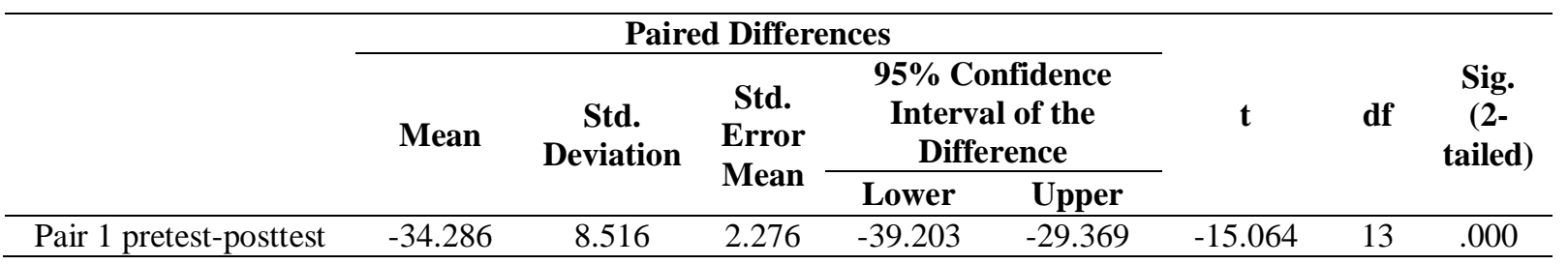

Berdasarkan tabel 3 hasil uji T nilai pretest dan posttest siswa SDN 1 Ngembel maka diperoleh nilai $t$ tabel sebesar 2.160369 sedangkan thitung sebesar -15.064. Dari hasil ini bisa disimpulkan bahwa nilai ttabel > thitung sehingga Ho ditolak jadi terdapat pengaruh media pohon bersuara berbasis model Children Learning in Science terhadap prestasi belajar Fisika siswa di SDN 1 Ngembel. 
TABEL 4. Hasil Uji T Siswa SDN 1 Ngembel

\begin{tabular}{|c|c|c|c|c|c|c|c|c|}
\hline & \multicolumn{5}{|c|}{ Paired Differences } & \multirow{3}{*}{$\mathbf{t}$} & \multirow{3}{*}{ df } & \multirow{3}{*}{$\begin{array}{l}\text { Sig. } \\
(2- \\
\text { tailed })\end{array}$} \\
\hline & \multirow[t]{2}{*}{ Mean } & \multirow[t]{2}{*}{$\begin{array}{c}\text { Std. } \\
\text { Deviation }\end{array}$} & \multirow{2}{*}{$\begin{array}{l}\text { Std. } \\
\text { Error } \\
\text { Mean }\end{array}$} & \multicolumn{2}{|c|}{$\begin{array}{l}\text { 95\% Confidence } \\
\text { Interval of the } \\
\text { Difference }\end{array}$} & & & \\
\hline & & & & Lower & Upper & & & \\
\hline Pair 1 pretest-posttest & -38.214 & 9.924 & 2.652 & -43.944 & -32.484 & -14.408 & 13 & .000 \\
\hline
\end{tabular}

Berdasarkan tabel 4 hasil uji T nilai pretest dan posttest siswa SDN 2 Ngembel maka diperoleh nilai t tabel sebesar 2.160369 sedangkan thitung sebesar -14.408. Dari hasil ini bisa disimpulkan bahwa nilai ttabel > thitung sehingga Ho ditolak jadi terdapat pengaruh media pohon bersuara berbasis model Children Learning in Science terhadap prestasi belajar Fisika siswa di SDN 2 Ngembel.

\section{PENUTUP}

Berdasarkan hasil penelitian bisa disimpulkan bahwa pembelajaran yang dilakukan di SDN 1 Ngembel dan SDN 2 Ngembel berdasarkan hasil wawancara yang dilakukan peneliti kepada guru dan siswa selama ini hanya dilakukan dengan metode ceramah dan tes saja. Tahap-tahap pada model Children Learning in Science digunakan dalam penyusunan perangkat pembelajaran dalam bentuk RPP selama 4 kali pertemuan. Media pembelajaran pohon bersuara berbasis model Children Learning in Science pada penelitian ini merupakan media pembelajaran yang berasal dari imitasi pohon dengan ditambah dengan daun yang didesign menggunakan kertas karton berwarna yang dibentuk menjadi daun sesuai dengan design yang sudah ditentukan. Berdasarkan hasil perhitungan dengan Uji T SPP maka disimpulkan bahwa terdapat pengaruh media pohon bersuara berbasis model Children Learning in Science terhadap prestasi belajar Fisika siswa baik di SDN 1 ataupun SDN 2 Ngembel.

\section{UCAPAN TERIMAKASIH}

Terimakasih kepada pihak pemberi dana penelitian yaitu Kemenristekdikti, seluruh pimpinan dan karyawan STTKD Yogyakarta yang selalu memberikan bantuan dan support, para guru serta siswa SDN 1 Ngembel dan SDN 2 Ngembel yang sudah membantu proses penelitian sehingga bisa berjalan secara lancar.

\section{REFERENSI}

[1] Desmita, Psikologi Perkembangan Peserta Didik, Bandung : Remaja Rosda, 2011.

[2] Susanto, A., Teori Belajar dan Pembelajaran di Sekolah Dasar, Jakarta: Kencana Prenada Media Group, 2014.

[3] Suharjo, Mengenal Pendidikan Sekolah Dasar Teori dan Praktek, Jakarta: Departemen Pendidikan Nasional Direktorat Jendral Pendidikan Tinggi Direktorat Ketenagaan, 2007.

[4] Slameto, Evaluasi Pendidikan, Jakarta: Bumi Aksara, 2001.

[5] Anwar, Muzikka, Penerapan Pembelajaran CLIS (Children Learning In Sience) untuk Meningkatkan Hasil Belajar Siswa, Jurnal Ilmiah Mahasiswa (JIM) Pendidikan Fisika. Vol. 1 No.4, pp. 1574-159, Januari. 2017.

[6] Samatowa, Usman, Pembelajaran IPA di Sekolah Dasar, Jakarta: PT. Indeks, 2010.

[7] Sugiyono, Metode Penelitian Kuantitatif Kualitatif \& RND, Bandung: Alfabeta, 2010. 